\title{
Meandry péče: když muži doma pečují o ženy s demencí
}

\section{Dita Jahodová}

\section{Meanders of Care: When Men Take Care of Women with Dementia at Home}

\begin{abstract}
In the Czech Republic, it is women who are usually the primary carers of elderly family members, while men tend to be less involved and perform more concrete, visible care tasks. In this article I focus on the cases of men acting as the primary carer for a wife with dementia at home in cooperation with respite services. The data are drawn from an analysis of participant observations in the carers' households and from an analysis of semi-structured interviews with the men acting as primary carers and with respite services workers. This article shows the repertoires of care that have been used by men as caregivers and points out the limitations attached to distinguishing and categorising care as 'female' and 'male'. It investigates gendered aspects of long-term caring at home and shows how men in the role of primary carers deal with the challenging situations that they face while providing everyday care at home.
\end{abstract}

Keywords: men as caregivers, gender, home care, care of women with dementia

Jahodová, Dita. 2021. Meandry péče: když muži doma pečují o ženy s demencí. Gender a výzkum / Gender and Research 22 (2): 87-109, http://dx.doi.org/10.13060/gav.2021.021.

Péče o staré lidi v domácím prostředí se stává čím dál aktuálnějším tématem. Rodinní př́slušníci a příslušnice zajištujuí více než 80 \% péče o staré lidi v České republice (Dudová, Vohlídalová 2018; Dudová 2015). Česká republika se tak raadí k zemím s nejvyšším objemem neformální péče v Evropě (Dudová 2015). O člověka s demencí se běžně starají zhruba dva až tři rodinní príslušníci, prričemž velká část lidí s demencí žije doma (Mátl, Mátlová, Holmerová 2016). Domácí prostředí hraje důležitou roli v péči o lidi s demencí, a to jak z hlediska poskytování péče, tak z hlediska soudržnosti jednání lidí s demencí (Synek et al. 2017). Obecně u starších osob bývá domov spojován s představou stálého či pozvolna se proměňujicího prostředí, jehož význam s príbývajícím věkem "stoupá z důvodu rostoucí disability a snižující se mobility, ale 


\section{NV STATI / ARTICLES}

také na úrovni posilování autonomie" (Vidovićová et al. 2013: 63). Pro stárnoucí lidi $s$ demencí představuje domov většinou známé prostředí, v němž se cítí bezpečně. Socioprostorové uspořádání domova, které je utvářeno sociálními a materiálními praktikami, zároveň významně ovlivňuje poskytování péče (Dyck et al. 2005).

$\checkmark$ domácím prostředí pečuji o stárnoucí rodinné příslušníky převážně ženy (Chaloupková Klímová 2012). Avšak to neznamená, že by se muži do péče nezapojovali vưbec. Ženy jsou většinou primárními pečovatelkami a muži vypomáhají s konkrétními úkony, jako je např. odvoz na lékařské vyšetření, fyzická př́tomnost v bytě s nemocným rodinným př́slušníkem, asistence při přesunu z lůžka na vozík, při nástupu do auta atp. Zároveň muži fungují jako psychická podpora primárních pečovatelek v náročných situacích. Zapojení mužů do péče v takových případech spočívá především v péči o primární pečující (Dudová, Volejničková 2014). V tomto textu ovšem v hledáčku mé pozornosti budou muži, kteří se jako primární pečující starají o své manželky s demencí v domácím prostředí ve spolupráci s odlehčovacími službami. Pomocí etnografického výzkumu přibližím, jaké repertoáry péče muži v pozici primárních pečujících používají, když doma pečují o ženy s demencí, a jak svým pečováním narušují esencialistickou představu genderových rolí.

Na nižším zapojení mužů do péče o stárnoucí rodinné příslušníky a př́islušnice se podílí řada faktorů. $V$ průběhu socializace, do níž vstupují genderové normy, stereotypy a očekávání, jsou dívky intenzivněji vedeny k péči o druhé než chlapci (Oakley 2000). Péče je spojována s tradiční rolí ženy jako pečovatelky, kterou si navíc mnohé ženy internalizují, což napomáhá udržovat ve společnosti genderově stereotypní představu, že muži se nedokážou postarat o druhé tak dobře jako ženy (Arber, Gilbert 1989; Přidalová 2006). Vzhledem k přetrvávající genderové dělbě práce, díky níž je péče považována za práci žen, zastávají muži spíše pozici asistujících pečujících (Russell 2007a). Volba ženy jako primární pečovatelky bývá v mnohých rodinách vnímána jako „přirozená, samožrejmá, správná či jediná možná" (Dudová, Vohlídalová 2018: 223). V důsledku přetrvávající genderové dělby práce a kulturních norem spojených s péčí si ženy nezřídka volí takové zaměstnání, které Ize snadněji sladit s péčí o děti a stárnoucí rodinné př́slušníky (Hašková, Dudová 2017). Péče proto vstupuje i do pracovní biografie žen, zatímco u mužů se s péčí v pracovní biografii př́liš nepočítá. Do rozhodování, kdo bude primárním pečujícím, vstupuje i ekonomický faktor. Vzhledem k přetrvávající horizontální a vertikální segregaci pracovního trhu zastávají ženy mnohdy hưře placené pozice než jejich manželé či partneři. Nejde ovšem jen o strukturální nerovnosti na pracovním trhu; i na stejné pracovní pozici dostávají ženy zhruba o 11 \% nižší mzdu než muži (Křížková et al. 2019). Navzdory snahám zapojit muže více do péče, at již o děti či stárnoucí rodinné přílušníky, představa, že by takové rozhodnutí mohlo pro rodinu znamenat výrazný finanční propad nebo by ho nemusela finančně zvládnout, může být v některých rodinách při jejich volbě klíčo- 
vá. Rozhodnutí, že se primární pečující stane žena, se potom jeví jako „schůdnější, jednodušší a praktičtějši" (Dudová, Vohlídalová 2018: 223).

Nižší zastoupení mužů Ize vysledovat nejen v rámci neformální péče, ale rovněž u pečujicích profesí, mezi něž patří i odlehčovací služby. ${ }^{1}$ Podobně jako v případě primárních pečujících je i v př́ipadě odlehčovacích služeb důvodem spojování péče se ženami, dále se na této skutečnosti podílí přetrvávající nedostatečné finanční i společenské ohodnocení péče a s tím úzce spojená feminizace těchto služeb (Janebová 2008). Navíc jak poukazuje Helena Haškovcová (2010), dlouhodobá péče o seniory a seniorky není považována za atraktivní, protože v řadě prípadư se při ní neprojevuje příznivější vývoj. V neposlední řadě jsou to předsudky a zažité konvence, které udržují v některých lidech rezervovaný, až odmítavý postoj vưči mužům jako profesionálním pečujícím. Zkušenosti asistentek a asistenta odlehčovacích služeb, s nimiž jsem měla možnost $v$ rámci terénního výzkumu hovořit, ukazují, že některé rodiny nechtějí, aby o jejich př́ibuzné pečoval muž. Jsou zvyklé, že péči doma poskytují ženy, at již jde o matku, dceru, babičku, tetu, kamarádku nebo asistentku odlehčovacích služeb. Nedovedou si představit, že by se jejich príbuznému či př́buzné věnoval muž. $\checkmark$ některých rodinách pomyslnou nepřekročitelnou hranici tvoří hygiena intimních partií těla. Je pro ně neakceptovatelné, aby muž asistoval ženě při sprchování, výměně inkontinenčních pomůcek atp. Jinde přetrvává přesvědčení, že muži nedokážou tak vlídně, trpělivě a s respektem pečovat jako ženy. Někdy se též jedná prímo o prání osoby, které má být asistence poskytována. $V$ případě, že má být věnována péče ženě, jistou roli může sehrát i představa, že si ženy budou lépe rozumět. Odmítnutí muže jako pečovatele je mnohdy spojeno se zažitými konvencemi a na ně navázanou nedůvěrou z nového, neznámého, nevyzkoušeného, o čem nemají dostatek informací.

Existují ovšem rodiny, které př́ímo vyžadují, aby se o jejich příbuzné staral muž, a rodiny, pro něž pohlaví člověka, jenž bude poskytovat odlehčovací služby jejich příbuzným, není podstatné. Zároveň existují rodiny, v nichž na sebe berou roli primárních pečujicích muži. Jde většinou o muže pečující o své stárnoucí manželky či partnerky. Míra jejich zapojení do péče bývá srovnatelná s ženami, jež se starají o své manžele nebo partnery. Primárními pečujícími se stávají i muži, kteří pečují o své rodiče. Jedná se zejména o nesezdané muže, prípadně muže žijící geograficky nejbliž rodičům nebo nemají sestru (Arber, Gilbert 1989; Přidalová 2006).

$\checkmark$ této studii se budu zabývat případy, kdy se muži jako primární pečující doma věnují svým manželkám s demencí ve spolupráci s asistentem a asistentkami odlehčovacích služeb. Ráda bych tímto textem přibližila zkušenosti mužư s péčí o ženy

\footnotetext{
1 V roce 2019 pracovalo v oblasti zdravotní a sociální péče 313400 žen a pouze 81400 mužů (Čsú 2020). Statistiky zaměstnaných prímo v odlehčovacích službách dělené na ženy a muže se bohužel neprovádějí.
} 


\section{NV STATI / ARTICLES}

s demencí v domácím prostředí a přispěla ke zviditelnění jejich péče. Budu vycházet ze zúčastněného pozorování v rodinách a z polostrukturovaných rozhovorů, v nichž o svém pečování muži vyprávějí. Chtěla bych touto cestou ukázat, že muži dokážou pečovat s respektem, láskou a citem pro detail a zajistit chod domácnosti včetně vaření a hygieny, i když přitom narážejí na řadu překážek a nesnází. Zaměřím se na otázky: Jaké repertoáry péče používají muži, kteří pečují o ženy s demencí doma? Jakým způsobem do těchto repertoárů vstupuje gender? $\vee$ čem spočivají nesnáze, jimž muži čelí při každodenním zaopatřování žen v domácím prostředí? Jak se péče poskytovaná asistentem a asistentkami odlehčovacích služeb propojuje s péčí primárních pečujících a jak ji ovlivňuje?

\section{Muži a repertoáry péče}

Muži v pozici primárních pečujících některými svými praktikami narušují tradiční genderovou socializaci a jsou př́kladem toho, že esencialistické pojetí genderových rolí je neudržitelné (Russell 2007b). V prípadě primárně pečujicích mužư, kteří se starají o své manželky doma, nastává v souvislosti s péčí z genderového hlediska řada posunů: přerozdělení práce $v$ domácnosti; změna každodenního rytmu (aby stihli nakoupit, uvařit a postarat se o manželku i domácnost); přehodnocení důležitosti a potřebnosti některých činností včetně jejich postupného začleňování do každodenní agendy či naopak jejich upozad'ování. Primárně pečující muži tím, co a jak dělají, otevírají perspektivu, v rámci níž lze péči pojímat jako proces, jenž má genderový rozměr, avšak není podmíněn biologickým pohlavím pečující osoby (West, Zimmerman 2008). Vyjdeme-li z konceptualizace genderu, s níž přichází Judith Butler (2003), že gender má performativní charakter a je ustavován prostřednictvím stylizovaného opakování aktů, které jsou vnitřně diskontinuální, můžeme spatřit, jak je v procesu pečování gender utvářen v rámci určitých gest, tělesných projevů a při vyjadřování potřeb. V pojetí Butler (1993) není performování genderu voluntaristické, má regulativní charakter. $V$ tomto textu se budu opírat o konceptualizaci genderu v podání Judith Butler (2003) a Candace West s Donem H. Zimermanem (2008), podle nichž gender není souhrnem určitých vlastností, ale výsledkem určité sociální činnosti. Je třeba zdưraznit, že do péče vstupuje celá řada dalších faktorů, mezi nimiž významnou roli sehrávají sociomateriální podmínky ekonomické a lidské zdroje, jež mají neformální pečující k dispozici (Kuchařová et al. 2019). Pečování spoluutváŕi vztah mezi manžely, jeho dynamiku a hloubku. A zároveň se vztah mezi manžely spolupodílí na charakteru péče. Tyto dva procesy jsou velmi úzce provázány a vyvíjejí se v průběhu času. $\vee$ prípadě, že se do péče o ženy s demencí zapojí i asistenti a asistentky odlehčovacích služeb, pak i oni utváŕí charakter péče ve vzájemné v interakci s danou ženou, jejím manželem a prípadně dalšími rodinnými příslušníky.

Péče o ženy s demencí v domácím prostředí zahrnuje různé i protichůdné sady 
praktik, jež se v průběhu času proměňují a vyvijejí v závislosti na sociomateriálních podmínkách, na potřebách a možnostech žen s demencí a na dovednostech a schopnostech pečujících. Péči můžeme pojímat jako choreografii (Cussins 1996). John Law (2010) př́ímo hovoří o choreografii mnohočetné péče s otevřeným koncem, jež přidržuje dohromady a zároveň odděleně (ne)soudržné podoby péče. $V$ jeho pojetí péče představuje "soubor materiálních heterogenních praktik zahrnující nejen různé druhy subjektivit, ale též nástroje, technologie a jiné materiální složky, texty a zápisy" (Law 2010: 69). Pečování je vždy situované v čase a prostoru a realizuje se prostřednictvím specificky uspořádaných repertoárů (Law 2010). Jednotlivé repertoáry Ize charakterizovat jako sady činností, jež obsahují „určité jednání, ideály a vědění, a představují tedy určitý režim dělání rádu'" (Pols 2005: 3). Podle Jeannette Pols (2012) je každý repertoár "vnitřně konzistentní a má vlastní hierarchii hodnot" (2012: 164). Repertoáry péče Ize pojímat jako specifické mody uspořádávání péče, které jsou situované a skládají se z různých strategií, prvků, nástrojů, hodnot, jednání, dovedností, pohybů, projevů a gest, jejichž kompozice může být ovlivněna mimo jiné i genderem.

$\checkmark$ rámci svého zúčastněného pozorování v rodinách jsem identifikovala dva repertoáry péče, které muži zapojují do svého pečování o ženy s demencí. První jsem nazvala provozním repertoárem a druhý repertoárem laskavosti a radosti. Provozní repertoár muži využívají ke koordinaci péče a zajištování základních potřeb žen s demencí. Repertoár laskavosti a radosti používají na zpříjemnění každodenního života žen s demencí. $V$ dalších kapitolách príbližím, z čeho se tyto repertoáry skládají a jak za pomoci nich muži pečují o ženy s demencí v domácím prostředí.

\section{Metodologie}

Péče o lidi s demencí v domácím prostředí v České republice patří mezi oblasti méně probádané a zaslouží si intenzivnější pozornost (Mátl, Mátlová, Holmerová 2016). Zkoumání zkušeností a potřeb lidí žijících s demencí a těch, kdo o ně pečují, může přispět nejen k lepšímu porozumění životu s demencí, ale též k lepší organizaci péče o lidi s demencí, k posílení kvality jejich života a podpoře neformálních pečujících (Alzheimer Europe 2019). Z hlediska etiky výzkumu v této oblasti je zásadní, aby lidé s demencí byli zapojováni do výzkumu způsobem, jenž respektuje jejich autonomii a důstojnost a dává jim prostor se vyjádřit. Etické zapojení lidí s demencí do výzkumu nezahrnuje pouze ochranu zranitelných participujících, ale také posílení jejich hlasů, které je založeno na vzájemném respektu a ctí principy rovnosti (Alzheimer Europe 2019). Jedním z vhodných způsobů, jak zkoumat péči o lidi s demencí v domácím prostředí, je právě etnografie, jež umožňuje zaznamenávat a zvýznamňovat lidskou zkušenost, podporovat lidskou solidaritu a důstojnost a zároveň zachycovat mnohačetné pravdy působící v sociálním světě (Denzin 1997). 


\section{NV STATI / ARTICLES}

V tomto textu vycházím z dat z etnografického výzkumu o životě lidí s demencí a péči o ně, ${ }^{2}$ jenž jsem realizovala spolu s Michalem Synkem, Danou Hradcovou a Radkem Carbochem. ${ }^{3}$ Opírám se konkrétně o data ze zúčastněného pozorování (Emerson et al. 1995) v rodinách, do nichž jsem docházela v letech 2016-2018, dále o polostrukturované rozhovory (Flick 1998), které jsem uskutečnila s primárními pečujícími a se zaměstnanci a zaměstnankyněmi odlehčovacích služeb. Výběr rodin probíhal ve spolupráci s organizací, jež poskytuje terénní hospicovou službu a odlehčovací služby. ${ }^{4}$ Před zahájením pozorování v rodinách jsem s participujícími provedla ústní informovaný souhlas s účastí ve výzkumu a s následným využitím sebraných dat. S ohledem na udržení anonymity participujících jsem změnila jména rodinných př́ślušníků a př́slušnic, asistentů a asistentek odlehčovacích služeb i název organizace. Do rodin jsem docházela vždy s asistentem či asistentkou odlehčovacích služeb a mé pozorování trvalo po dobu jejich asistence. Do hledáčku mé pozornosti se tak dostaly nejen praktiky primárně pečujicích mužů, ale i odlehčovacích služeb. V případě první rodiny byla poskytována asistence ženě s pokročilou demencí čtyři až pět hodin denně od pondělí do pátku. Do druhé rodiny, s níž jsem ve výzkumu spolupracovala, chodily asistentky ke dvěma ženám třikrát týdně (v pondělí na hodinu, ve středu na hodinu a v pátek na dvě hodiny). Jedna žena měla demenci a druhá těžké onkologické onemocnění.

Pozorování v rodinách za př́tomnosti asistenta či asistentek odlehčovacích služeb, při němž jsem se podobně jako J. Pols (2005) soustředila na uskutečňování/vykonávání péče, bylo podnětné $z$ hlediska koordinace péče o ženy s demencí v domácím prostředí. Mělo ovšem zároveň limit v tom, že jsem nemohla pozorovat primárně pečující muže, jak se starají o ženy sami. Na jejich zkušenosti a přístupy k péči o manželky s demencí jsem se doptávala prostřednictvím polostrukturovaných rozhovorů. Na základě zúčastněného pozorování v rodinách jsem vytvořila jeden scénár̆ rozhovoru s primárně pečujícími muži a druhý scénár̆ rozhovoru se zaměstnanci a zaměstnankyněmi odlehčovacích služeb.

Během zúčastněného pozorování jsem si dělala terénní poznámky, které jsem poté v programu Atlas.ti opatřila komentárii a okódovala. Podobným způsobem jsem postupovala při zpracování dat z polostrukturovaných rozhovorů. $\vee$ další fázi analýzy

\footnotetext{
2 Tento etnografický výzkum byl proveden za podpory grantu č. 15-32942A-P09 AZV Ministerstva zdravotnictví České republiky „Case management jako komplexní intervence pacientů s demencí, její vliv na užití zdrojů a kvalitu života pacientů a pečujících“. Projekt byl schválen etickou komisí Gerontologického centra.

3 Na základě těchto dat vznikl náš společný text „O (ne)soudržnosti pečování: Mnohočetné ontologie života lidí s demencí" (Synek et al. 2017).

${ }^{4}$ Chtěla bych poděkovat vedení Přístavu a zaměstnaným v odlehčovacích službách za jejich důvěru pustit mě do terénu, v němž působí, a za ochotu propojit mě s rodinami, kde v té době poskytovali odlehčovací služby ženám s demencí v domácím prostředí.
} 
jsem již pracovala s daty ze zúčastněných pozorování a polostrukturovaných rozhovorů dohromady: hledala jsem vztahy mezi úryvky v rámci jednotlivých kódů a tvořila memo poznámky. Po specifikaci výzkumných otázek vznikal výsledný text propojováním a rozvíjením memo poznámek.

Při vyprávění příběhů o péči mužů o ženy s demencí v domácím prostředí skládám a propojuji data z polostrukturovaných rozhovorů a zúčastněných pozorování (Denzin 1997; Denzin, Lincoln 2008) takovým způsobem, že není vždy zcela zřejmé, zda konkrétní informace pochází z rozhovoru nebo zúčastněného pozorování. Vycházím z předpokladu, že v rámci kvalitativního výzkumu se na tvorbě poznání podílejí nejen badatelé a badatelky, ale i participující (Letherby 2003; Denzin, Lincoln 2008). $\checkmark$ této souvislosti jsem si vědoma, že participující v rozhovorech mohou prezentovat sebe a své príběhy v návaznosti na svou představu o badateli či badatelce a cílech výzkumu (Letherby 2003). Jejich sebeprezentace může být ovlivněna i společenskými normami a dalšími faktory.

\section{Představení rodin a organizace Přístav 5}

\section{Liškovi}

Pan Liška pracoval do svých 85 let. Když se u jeho manželky rozvinula demence, rozhodl se skončit v práci a starat se o ni. Paní Lišková byla usměvavá komunikativní dáma, která žila s pokročilou demencí doma s manželem několik let. I při snížené pohyblivosti velmi ráda vyrážela na vozíku na procházky na oblíbená místa. Pan Liška se staral o svou manželku žijící s demencí několik let sám s menší výpomocí své dcery a syna. $V$ posledních třech letech života paní Liškové se na péči o ni intenzivně podílela organizace Přístav. Rozsah péče ze strany Přístavu se postupně zvětšoval v návaznosti na potřeby paní Liškové a ubývající síly pana Lišky. Většinou za paní Liškovou docházel asistent Petr, s nímž si vytvořila velmi blízký vztah. Poté, co si paní Lišková zlomila nohu $v$ krčku, navštěvoval pan Liška svou manželku v nemocnici. Jejich blízké pouto na čas přerušil zákaz návštěv v nemocnici během chřipkové epidemie. Paní Lišková v té době dostala zápal plic, kterému poté po převozu do LDN podlehla. Pan Liška se snažil do LDN přenést alespoň kousek jejich domova v podobě oblíbené deky.

\section{Pařízkovi}

Panu Pařízkovi bylo přes 80 let, když se u jeho manželky začala rozvíjet demence spolu s Parkinsonovou chorobou. Postupně pro ni bylo náročné skládat dohromady věty, občas těžko hledala výrazy k pojmenování toho, co chtěla vyjádřit. Intenzivně

\footnotetext{
${ }^{5} \mathrm{~V}$ této kapitole vycházím z dat, která jsem sebrala v rámci zúčastněného pozorování. Jsou složena z terénních poznámek z pozorování v rodinách a doptávání se participujících.
} 


\section{NV STATI / ARTICLES}

se jí třásly ruce a mluvení ji vyčerpávalo. Na vzniklou situaci tehdy reagovala sestra pana Pařízka. Nabídla mu, že se $k$ nim prestěhuje a pomůže mu jak s péčí o paní Pařízkovou, tak s domácností. Krátce po nastěhování k Pařízkovým jí však lékaři diagnostikovali onkologické onemocnění v pokročilém stadiu. Pan Pařízek se tak ocitl v situaci, kdy bylo potřeba se postarat nejen o manželku a domácnost, ale i o sestru. Do rodiny začala docházet hospicová služba z organizace Přístav. Nejdříve Přístav poskytoval domácí hospicovou péči sestře pana Pařízka, když se její stav po několika měsících stabilizoval, nabídl jí přechod do odlehčovací služby. Péči poskytovanou odlehčovacími službami Přístavu postupně začala využívat i manželka pana Pařízka. Asistentky odlehčovacích služeb byly schopné se velmi dobře přizpůsobit aktuálním potřebám obou žen a po dohodě s nimi jim pomohly, s čím potřebovaly. S péčí o obě ženy významně panu Pařízkovi vypomohla paní Elena, která začala k Pařízkovým docházet. Paní Elena byla rodinná známá z dob, kdy Pařízkovi žili v emigraci a ona se tam starala o jednoho jejich společného známého. Po dvou letech, kdy se zdravotní stav sestry pana Pařízka zhoršil, přijal ji Přístav opět do domácí hospicové služby a ona zemřela v klidu doma, obklopena blízkými lidmi. Paní Pařízová, rovněž po zhoršení zdravotního stavu, přešla do domácí hospicové služby Přístavu. Pan Pařízek spolu se svými syny ji po vyšetření v nemocnici nenechali hospitalizovat. Spojili se s domácí hospicovou službou Př́stavu a umožnili paní Pařízové zemřít pokojně doma v kruhu rodiny.

\section{Př́́stav}

Organizace Přístav poskytuje terénní hospicovou službu a odlehčovací služby. Specializuje se především na domácí hospicovou péči a odlehčovací služby provozuje spíše doplňkově. Dále Přístav nabízí poradenství týkající se péče o nevyléčitelně nemocné a jednorázovou konziliární návštěvu lékaře a zdravotní sestry, a to jak doma, tak v nemocnici či jiném zařízení.

Domácí hospicovou péči zajištúuje multidisciplinárním tým složený z lékařů a lékařek, zdravotních sester, specialisty na kompenzační pomůcky, sociálních pracovnic, psychosociálních pracovnic, psychoterapeuta, asistentů a asistentek odlehčovacích služeb, duchovních a dobrovolníků a dobrovolnic. Odlehčovací služby má na starosti sociální pracovnice, která vede tým asistentek a asistentů odlehčovacích služeb. ${ }^{6}$

\footnotetext{
${ }^{6}$ Porady multidisciplinárního týmu probíhají jednou týdně a probírá se na nich aktuální stav hospicových klientů a klientek. Členové a členky multidisciplinárního týmu se zastaví u každého hospicového klienta a klientky zvlášt a předávají si mezi sebou informace o vývoji zdravotního stavu a průběhu péče o daného člověka. Asistenti a asistentky odlehčovacích služeb mají ještě svou zvláštní poradu, kde se věnují jednotlivým klientům a klientkám odlehčovacích služeb. Porady v rámci obou služeb jsou důležité nejen z důvodu sdílení aktuálních informací a předávání zkušeností, ale i z hlediska vzájemné zastupitelnosti a koordinace péče.
} 
Rozsah péče odlehčovacích služeb se v jednotlivých rodinách liší. Záleží na potřebách konkrétní rodiny a na aktuální kapacitě. Pokud má Přístav kapacitu, je schopen rozsah péče u klientů a klientech odlehčovacích služeb postupně navyšovat. Když je klient či klientka odlehčovacích služeb převezen/převezena do nemocnice, práce Přístavu končí. Lze ji obnovit, pokud se rodina rozhodne pečovat o svého člena nebo členku doma. Když má zájem o domácí hospicovou službu, spojí se lékař či lékařka Přístavu s ošetřujícím lékařem nebo ošetřující lékařkou v nemocnici a domluví se na převozu, aby přechod mezi nemocnicí a domovem byl pokud možno co nejplynulejší. Aktivita ze strany rodiny je klíčová pro rozběhnutí či obnovení péče Přístavu.

\section{Přechod do pozice primárního pečujícího}

Když se u paní Liškové rozvinula demence, považoval pan Liška rozhodnutí pečovat o manželku doma za logické vyústění vzniklé situace a součást závazku vůči manželce $v$ rámci jejich společného soužití. Péči o ni měl spojenou jednak s odpovědností vůči ní a zároveň s určitou formou reciprocity péče v rodině - manželka se starala o děti, pokud vyžadovaly péči, a nyní on se postará o manželku, když potřebuje péči ona. $\checkmark$ rozhovoru, který jsme spolu vedli, zastával názor, že pozici primární pečující osoby může vykonávat člověk bez ohledu na to, zda se jedná o ženu či muže.

Mně to prǐšlo jako povinnost. Vübec jsem nad tím neuvažoval. Když manželka byla doma s malými dětmi, tak také nechodila do práce. Já v tomhle nevidím, že by se měly dávat přednosti. Každý, pokud může, tak může pečovat. (pan Liška)

Jak ukazují ve svém výzkumu Dolors Comas-d'Argemir a Montserrat Sorronellas (2019), morální povinnost a př́buzenská reciprocita jsou v současnosti pro muže častým důvodem, proč se stávají primárními pečujícími. Podle Comas-d'Argemir a Sorronellas (2019) při rozhodování, kdo bude pečovat, začíná hrát ústřední roli príbuzenství namísto genderu. Inspirovány koncepty "dělání genderu“ přicházejí D. Comas-d'Argemir a M. Sorronellas (2019) s konceptem "dělání príbuzenství", který po vzoru J. Butler $(1990,2004)$ chápou jako performativní akt. Způsoby "dělání genderu" a "dělání príbuzenství" jsou podle nich „založeny na opakovaném vyjednávání toho, co je považováno za vhodné pro uspokojení potřeb osob, o něž se pečuje" (Comas-d'Argemir, Sorronellas 2019: 334).

Reciprocita péče byla pro pana Lišku součástí nejen jeho vztahu s manželkou, ale i každodenního rodinného života. Jak vyplynulo z rozhovoru, nepovažoval starost o chod domácnosti a péči o rodinu výhradně za doménu žen. Během soužití s manželkou a dětmi se zapojoval do tohoto chodu, což mu později významně usnadnilo přechod mezi zaměstnáním a péčí o manželku, když se u ní rozvinula demence. 


\section{NV STATI / ARTICLES}

My byli rodina, kde všichni museli pracovat. Přijel jsem ze školy, dal jsem vodu na polévku, vyvětral, zametl, ustlal postele atd. Bylo to úplně běžné, takže tady to (starost o domácnost - pozn. autorky) mi vůbec nevadilo. (pan Liška)

Pan Liška byl zvyklý nakupovat, vařit i uklízet, čehož jsem si všimla i při svém pozorování. Vždy když jsem $\mathrm{k}$ nim přišla domů, bylo v bytě uklizeno a v lednici měla paní Lišková připravený oběd, který jí pan Liška uvařil. Asistent či asistentka odlehčovacích služeb jí pak oběd ohřáli nebo zabalili s sebou na vycházku. Přechod mezi prací a péčí o manželku doma mu navíc usnadnila skutečnost, že během života vedl chemickou laboratoř a byl zvyklý koordinovat lidi a organizovat si práci. Organizační schopnosti a dovednosti, které se mu osvědčily v práci, přenesl i domů - do péče o manželku a domácnost. Přešel z managementu laboratoře do managementu péče v kombinaci s prímou péčí.

Zjistil jsem, že jsem dost systémový člověk, což nevzniklo náhodou. Na vysoké škole jsem vedl laboratoř. Měl jsem na starosti lidi, programy, bezpečnost a všechno. Byl jsem na to (plánovat si a organizovat činnosti, aby v nich měl prehled - pozn. autorky) zvyklý. Uspořádal jsem si to (činnosti spojené s chodem domácnosti a péči o manželku - pozn. autorky) úplně automaticky. (pan Liška)

Podle Richarda Russella muži, kteří se stali primárními pečujícími, dokázali celkem úspěšně přejít z režimu práce na pracovním trhu do práce v podobě péče o manželku díky kombinaci prímé péče a zajištění poskytování péče organizacemi či jednotlivci, kteří se na péči v domácím prostředí specializuji (Russell 2007a). V prípadě pana Lišky byl přechod mezi prací a péčí o manželku výrazně usnadněn jeho předchozí aktivní participací na chodu domácnosti. V jeho př́padě odlehčovací služby nebyly klíčové při přechodu z práce na pracovním trhu do práce v podobě péče o manželku. Jejich význam se ukázal až později, když mu začaly ubývat síly a paní Lišková potřebovala intenzivnější péči. Díky intenzivnímu zapojení odlehčovacích služeb Přístavu, konkrétně především péči asistenta Petra, mohla žít paní Lišková i s pokročilou demencí doma.

Pan Pařízek byl do péče o svou manželku a sestru vržen bez předchozího intenzivnějšího zapojení do chodu domácnosti. Než jeho manželka onemocněla, zajištovala chod domácnosti ona a on jen př́ležitostně s něčím vypomohl. Neměl zkušenosti s vařením, praním a žehlením, ani v tomto ohledu neměl na co navázat. Vzhledem k tomu, že se řadu činností spojených s péči o manželku a sestru učil, soustředil se především na zajištění základních každodenních potřeb obou žen - jídla, pití, hygieny, léků. Navíc, na rozdíl od pana Lišky, se staral o dvě ženy, z nichž každá měla trochu jiné potřeby a zvyklosti. Sestra pana Pařízka již nemohla chodit a trávila celý den v polohovací posteli. Pan Pařízek jí nosil jídlo a pití do postele. Paní Pařízková 
zvládla s obtižemi chodit po bytě. Nicméně, jak se u ní rozvíjela demence, ubývalo jí sil a preferovala častěji zưstávat v posteli. Pan Pařízek se ji snažil rưzně motivovat, aby se pohybovala. Napríklad jí jídlo servíroval v obývacím pokoji, aby se alespoň trochu prošla. Navíc paní Pařízková potřebovala při jídle asistenci, protože se jí třásly ruce. Nešlo tedy jen o to jídlo uvařit, ale také ho podat a všechno dobře načasovat, pomoci manželce z postele do obývacího pokoje, nandat jídlo na talír, pomalu jí ho př́borem podávat, což pro něho nebylo vždy snadné, a zároveň u toho jíst vlastní jídlo, aby zcela nevystydlo.

"Nějak to koulíme", byla věta, kterou jsem slýchávala od pana Pařízka často. Tato věta velmi dobře vystihuje náročnou situaci, v níž se pan Pařízek spolu se svou manželkou a sestrou ocitli, i to, jak se ji snažili zvládnout. Obsahuje reflexi pana Pařízka, jenž dělal, co mohl, a zároveň si uvědomoval, že jeho péče není vždy pro obě ženy ideální. Odkazuje k jeho snaze pečovat o obě ženy, jak nejlépe dokázal, což ho stálo nemalé úsilí. A v neposlední řadě je tato věta spojena s trpělivostí a vlídností obou žen, s níž príijímaly péči, nehledě na drobné výčitky ze strany sestry pana Pařízka.

\section{Repertoáry pečování}

Pan Pařízek do pečování o obě ženy velmi často zapojoval provozní repertoár, v jehož rámci koordinoval poskytování péče odlehčovacími službami a terénní hospicovou službou. Vedl si k pečování i diár̆. Měl velký notes, kam si zapisoval jednotlivé úkoly, asistence a návštěvy: kdy přijde asistentka odlehčovacích služeb či lékařka z Prístavu, kdy dorazí zdravotní sestra z jiné organizace, kdy má jeho manželka lékařské vyšetření, kdy přijdou vnoučata pomoci s úklidem bytu, co je potřeba nakoupit a zařídit atd. Prostřednictvím managementu péče spoluorganizoval život ženě, sestře, ale i sám sobě (Přidalová 2006; Russel 2007a). Jedna z asistentek odlehčovacích služeb Přístavu ho prrímo označila za manažera provozu. Přestože mu organizování péče zabralo hodně času a energie, snažil se podle svých možností věnovat i prímé péči o obě ženy.

Provozní repertoár péče používal pana Pařízek nejen při organizování péče, ale i při zajištění základních každodenních potřeb. Nakupování, příprava jídla, mytí nádobí, praní prádla a běžný úklid bytu ho natolik vytěžovaly, že na některé činnosti už mu nezbývala kapacita a nevěnoval jim pozornost, prestože byly pro obě ženy dưležité. Jednalo se například o třídění prádla. Stávalo se, že ženám zaměnil oblečení či spodní prádlo. Třídění prádla nepřikládal př́liš velkou důležitost, ovšem spiše než o nezájem a neochotu vyslyšet praání obou žen šlo v jeho prípadě o nastavení priorit a rozložení sil. $V$ důsledku tradiční dělby práce $v$ rodině neměl pan Pařizek řadu činností osvojených a musel se je učit. Navíc tím, že se řadu z nich učil a neměl je dobře osvojené, trvaly mu déle než panu Liškovi a více ho unavovaly. 


\section{NV STATI / ARTICLES}

Na zapojení repertoáru laskavosti a radosti do pečování nezbývala panu Pařízkovi př́liš kapacita. Situace, v níž se ocitl, a sociokulturní podmínky, které ovlivňovaly možnosti jeho pečování (včetně např. předchozí tradičně nastavené genderové dělby práce v domácnosti), mu neposkytovaly př́liš prostor, aby věnoval pozornost jemným detailưm. Činnostem a dotekům, jež dělají péči blízkou a vzájemnou. Drobnostem, které potěší a zpříjemní někdy poněkud monotónní běh dne.

Pan Liška zapojoval do pečování o paní Liškovou jak provozní repertoár péče, tak repertoár laskavosti a radosti, kterým zpříjemňoval každodenní život své manželce. $\checkmark$ procesu pečování lze přecházet $z$ jednoho repertoáru péče do druhého. $V$ této souvislosti hovoři J. Pols (2005) o přepínání mezi repertoáry. Při přepínání mohou nastat větší či menší obtíže včetně střetů mezi repertoáry. V takových prípadech otevřená diskuse „pomáhá urovnávat choulostivé spletitosti každodenního života, nebot vede k jasnějšímu vyjádření - často nevyslovených - vzorců hodnot, vědění a jednání" (Pols 2005: 4). Možnost přecházet mezi repertoáry péče je ovšem navázána na sociomateriální podmínky, v nichž pečování probíhá, což dokládají přiběhy obou primárních pečujících.

Provozní repertoár využíval pan Liška nejen pro časové rozvrhování péče a její koordinaci s odlehčovacími službami Přístavu, ale také pro prostorové uspořádání věcí potřebných $k$ péči. Pan Liška uspořádal věci v bytě přehledně a logicky soudržně, takže bylo možné se $v$ nich rychle zorientovat, což Petrovi a dalším asistentkám odlehčovacích služeb z Přístavu usnadnilo obsluhu paní Liškové. Jednotlivé skříňky v pokoji paní Liškové byly popsány tak, že každý, kdo do pokoje vstoupil, rychle zjistil, kde má jaké oblečení, kde jsou ručníky a toaletní potřeby, včetně inkontinenčních pomůcek. Zároveň pan Liška upravil koupelnu a pokoje bytu tak, aby se v nich mohla paní Lišková snadněji pohybovat, at' už s jeho oporou, nebo s pomocí Petra či jiných asistentek. Pan Liška přistupoval k péči o paní Liškovou komplexně a systematicky. $\checkmark$ jeho pojetí péče zahrnovala i úpravy prostoru, aby se v něm paní Liškové dobře žilo, a změny v uspořádání věcí, aby se daly v bytě snadno najít a byly rychle po ruce. Péči o manželku přizpưsobil i časovému rozvržení každodenních činností. Vedl si diář, do kterého si zapisoval, co je potřeba zařídit a nakoupit, kdy bude mít čas potkat se s kamarády nebo si jít zaplavat.

"Já mám rád systém a do dneška ho dodržuju. Mám diáře, abych věděl." (pan Liška)

S pomocí diáře organizoval pan Liška nejen péči o manželku, ale i svůj čas a aktivity, včetně setkávání s přáteli. Diář mu pomáhal jednotlivé činnosti uspořádat tak, aby se mohl věnovat i sobě a svým zálibám.

Paní Lišková si ráno ráda přispala. Petr přicházel k Liškovým po deváté hodině. Pan 
Liška pred jeho příchodem připravil pro paní Liškovou snídani, kterou Petr podával paní Liškové po koupání. Zároveň připravil pro paní Liškovou i oběd, který si bud' brala s sebou na procházku, nebo jí ho Petr ohřál v mikrovInné troubě. Péče pana Lišky a Petra byla sladěná a výborně na sebe navazovala.

Petr se staral o paní Liškovou několik let a ve svém pečování o ni uplatňoval repertoár laskavosti a radosti. Věděl, jak ji potěšit, když se jí ráno nechtělo z postele. Poskytoval jí oporu, aby jí usnadnil cestu do koupelny, když se pro ni chůze stala náročnou a každý krok znamenal značné úsilí. Paní Lišková se nerada sprchovala, ale zato ráda zpívala. Aby jí dobu ve sprše zpř́ijemnil, naučil se kvůli ní pár písniček, které spolu při sprchování zpívali (Synek et al. 2017). Paní Lišková ani pan Liška nikdy neměli problém s tím, že je Petr muž a asistuje jí při hygieně intimních partí těla, což vyplynulo jak z rozhovorů s Petrem a panem Liškou, tak ze zúčastněného pozorování. Naopak, sprchování a mytí, včetně vstupu a výstupu z vany, probíhalo ve vzájemné souhře mezi paní Liškovou a Petrem. S respektem, vlídností a pozorností ke křehkosti a zranitelnosti paní Liškové.

Panu Pařízkovi podobně jako panu Liškovi pomáhala s péčí o obě ženy organizace Přístav. Asistentky odlehčovacích služeb Přístavu ovšem trávily s paní Pařízkovou a sestrou pana Pařizka mnohem méně času než Petr s paní Liškovou. Zároveň tím, že byly dvě a každá měla trochu jiné potřeby, byla péče pro pana Pařízka náročnější. $\checkmark$ tomto ohledu bylo pro pana Pařízka, ale i pro obě ženy velkou pomocí a vzpruhou, když k nim domů začala docházet paní Elena.

Když se objevila Elena, bylo to boži řizení. Jééé, to byla senzace. (...) Ted'už je to nádherné, když je tady Elena. Někdy udělá oběd. Třeba včera dělala ptáčky. Ona je zlatý člověk, zlatý člověk. (pan Pařízek)

Pro paní Elenu byla príprava jídla běžnou činností, a mohla se tak víc zaměřit na to, aby ženám jídlo chutnalo a dobře se jim jedlo. Bylo pro ni snadnější přizpůsobit se aktuálním potřebám a chutím žen než pro pana Pařízka. Zároveň byla trpělivější při podávání jídla paní Pařízkové. Nespěchala na ni a podávala jí jídlo pomalu. Pečování paní Eleny probíhalo v repertoáru laskavosti a radosti, který dával paní Pařízkové větší prostor se aktivněji zapojit. A to jak z hlediska výběru jídla, tak z hlediska jeho konzumace, kdy paní Pařízková udávala tempo podávání jídla.

Bylo by ovšem zjednodušující označit repertoár péče používaný paní Elenou za „„̌̌enský", zatímco repertoár používaný panem Pařízkem za "mužský”; a vytvořit tak spojnice mezi trpělivostí, vlídností, smyslem pro detail a tzv. „ženským” přístupem k péči. Repertoár laskavosti a radosti využíval při pečování i pan Liška a Petr. I jejich péče se vyznačovala trpělivostí, citlivou reflexí aktuálních potřeb osoby, o niž pečovali, a smyslem pro detail (Synek et al. 2017). Pečující praktiky pana Lišky a Petra jsou 


\section{STATI / ARTICLES}

príkladem toho, že rozdíly $v$ těchto praktikách nejsou podmíněny biologicky, ale socializací, zkušenostmi, znalostmi a dovednostmi, které lidé během života získávají. At' již zkušenosti a dovednosti nabyli prostřednictvím dělby práce v rodině, v níž vyrostli, nebo prostřednictvím předešlé aktivní participace na péči o děti a domácnost nebo jinými způsoby (například ve speciálních vzdělávacích kurzech a v profesionální praxi), jedná se o praktiky, jež se naučili. Jak s těmito zkušenostmi, znalostmi a dovednostmi nakládají, jak jsou schopni je reflektovat a rozvíjet, dále ovlivňuje jejich pečování a výběr repertoárů péče.

Petr podobně jako paní Elena používal při pečování repertoár laskavosti a radosti. Oběma šlo o to, aby péče byla př́ijemná. Petr pravidelně vyrážel s paní Liškovou na vozíku na procházky na její oblíbená místa. V zimě s rukavicemi, čepicí a dekou, do níž paní Liškovou zabalil, aby na vozíku neprochladla. Za teplého počasí se spolu občas stavili u řeky na pivo, které měla paní Lišková v oblibě. Petr cíleně do pečování zařazoval aktivity, z nichž měla paní Lišková radost a těšila se na ně. Paní Elena zase zjistila, že obě ženy mají rády dobrou kávu. Koupila ženám dobrou kvalitní kávu a udělala z pití kávy společenskou událost. Když šel pan Pařízek nakupovat a ona zůstala s ženami sama doma, uvařila kávu a společně ji pily u lůžka sestry pana Pařízka. Jak Petr, tak paní Elena pečovali o ženy velmi pozorně a přemýšleli o různých drobnostech, jak udělat ženám radost a zpř́jemnit jim den.

Tím, jaké repertoáry péče Petr, pan Liška a pan Pařízek používají při péči o ženy s demencí, narušuji genderově stereotypní dělení péče na "mužskou" a "ženskou". Svým pečováním ukazují, že neexistuje žádná jednolitá homogenní "mužská" péče. Různí muži pečují o ženy různě. U pana Pařízka Ize vysledovat zaměření péče především na zajištění základních materiálních potřeb. V prípadě pana Lišky a Petra je péče neoddělitelně spjata nejen se zajištěním základních materiálních potřeb, ale i s cíleným přemýšlením nad tím, čím ženu s demencí potěšit, a staráním se o to, aby se cítila př́ijemně, pohodlně a bezpečně. Každodenní praxi, kterou jsem měla možnost v obou rodinách pozorovat, mnohem lépe než dělení na "ženskou" a "mužskou" péči vystihuje pojímání péče jako interaktivního procesu, v rámci něhož pečující kladou dưraz na různé aspekty/hodnoty. Pro někoho spočívá péče především v zajištění provozních věcí a základních potřeb, pro jiného je nedílnou součástí péče i zpříjemňování každodenního života, a to bez ohledu na pohlaví pečující osoby.

Pojímání péče jako interaktivního procesu umožňuje zachytit vzájemnou spolupráci mezi pečující osobou a osobou, o niž se pečuje: jak mezi sebou vyjednávají rozhodnutí, co a jak se bude dělat; jak spolu zjednávají autonomii pečované osoby; jak pečující naslouchá potřebám osoby, o niž pečuje; jak vnímavě a s respektem přistupuje $k$ její zranitelnosti (Agich 2003; Black 2005; Synek et al. 2017).

Pojímáním péče jako interaktivního procesu se genderový rozměr nevytrácí. Naopak jej lze zachytit ve více rovinách. Gender je vetkán do sociokulturního kontextu 
osoby, o niž se pečuje. Vstupuje do interakce mezi pečujícím a pečovanou osobou a ovlivňuje očekávání a potřeby pečované osoby. Například sestra pana Pařízka byla v průběhu svého aktivního života dáma, která si potrpěla na to, aby krásně vypadala. Ráda nosila pěkné oblečení z kvalitních látek. I když ke konci svého života již nemohla chodit a trávila celé dny v posteli, bylo pro ni stále důležité, jak vypadá a co má na sobě. Bylo pro ni náročné přijmout, že pan Pařízek občas zaměnil její spodní prádlo se spodním prádlem své manželky. Saténové spodní prádlo pro ni bylo součástí její integrity. Tř́dění prádla se stalo častým předmětem jejich debat a jemných tenzí.

Pojímání péče jako interaktivního procesu umožňuje zachytit, jak se gender v procesu pečování „dělá". Jak je gender utvářen v každodenních interakcích mezi pečujícím a pečovanou osobou a zároveň jak tyto interakce strukturuje (West, Zimmerman 2008). Jak pečující spolu s pečovanou osobou genderovou odlišnost zjednávají, ale i narušují a popírají. „Dělání” genderu zahrnuje jak vytváření, tak i přetváření odlišnosti a vymezování se vůči normativním tlakům v určitých kontextech (Simpson 2009). V některých nemocnicích se např́klad od mužů očekává, že budou zvedat těžké pacienty a pacientky a postarají se i o agresivnější z nich. Nicméně v každodenní interakci se muži mohou vůči těmto normativním představám vzpírat a postupně je rozmělňovat (Simpson 2009).

\section{Nesnáze v pečování}

Pro mnohé primárně pečující muže, kteří se starají o své manželky, představuje největší problém př́prava jídla a vaření (Russell 2007b). Je to způsobeno především komplexitou úkonů, již příprava jídla vyžaduje, a jejich vzájemnou provázaností. R. Russell (2007b) prímo hovoří o food managementu, jenž zahrnuje sérii činností spojenou s prípravou jídla včetně plánování, koordinace a časového rozvržení. Než se muži stali primárními pečujícími, byla pro mnohé z nich příprava jídla ve své komplexitě neviditelná nebo složitě rozpoznatelná.

$\checkmark$ rodinách, kam jsem docházela na pozorování, bylo vaření velmi obtížné pro pana Paříka. Jak již bylo naznačeno výše, o společnou domácnost se z velké části starala jeho žena, dokud se u ní nerozvinula demence. Pan Pařízek se ocitl v situaci, kdy bylo potřeba, aby uvařil pro sebe i obě ženy. Zpočátku panu Pařízkovi pomáhaly s vařením lékařky a asistentky z Přístavu, jež chodily za jeho sestrou v rámci hospicové péče. Učily ho dělat jišsu, radily mu s omáčkami a přípravou masa, aby bylo měkké a dalo se dobře jíst. $\vee$ této souvislosti považuji za důležité vyzdvihnout, jak byly nastaveny odlehčovací služby $v$ Př́stavu. Asistentky odlehčovacích služeb byly schopné velmi pružně reagovat na potřeby pečujícího, a to i nad rámec své profesní činnosti, čímž výrazně přispěly $k$ udržení kontinuity péče $v$ domácím prostředí. Zajištění chutného jídla je důležitou součástí kvalitní péče o lidi s demencí (Hradcová et al. 2020). Pan 


\section{STATI / ARTICLES}

Pařízek se postupně naučil vařit několik jídel. Prioritou pro něho bylo, aby obě ženy měly pravidelně teplé jídlo, a již tolik nehleděl na to, co které z nich chutná a jak by jim prostřednictvím jídla mohl udělat radost a zpříjemnit den. Pan Pařízek péči o obě ženy v rámci provozního repertoáru nejen koordinoval, ale sám ji i často poskytoval. Pečování v provozním repertoáru nebylo u pana Pařízka ani tak otázkou osobní volby, ale spiše výsledkem sociomateriálních podmínek, jež mu nedávaly př́liš prostor, aby zapojoval i repertoár radosti a laskavosti.

Naopak pan Liška byl zvyklý vařit. Vyrostl v rodině, kde otec byl kuchař, a řadu kuchařských dovedností od něho odpozoroval. Zvládal sváteční jídla pro návštěvy i běžné každodenní vaření.

Protože jsme měli děti a stř́dali jsme se, tak jsem si ledacos pamatoval. Udělal jsem třeba svíčkovou a pozval syna, dceru a ještě nějaký přibuzný. Oni se na to vždycky těšili. Mưj otec byl vyučený kuchař a já se navykl dělat některé věci jako on. (pan Liška)

Pan Liška vařil s chutí a věděl, že svým vařením dokáže lidi potěšit. O jídle neuvažoval jen v rovině nasycení, ale i v rovině chuti, vůně, konzistence, vzhledu a radosti z jídla (Zgola, Bordillon 2013). Vaření jídla pro paní Liškovou u něho probíhalo v repertoáru laskavosti a radosti. Jak vyplynulo z mého pozorování, vařil své ženě na procházky husté polévky, protože jí chutnaly a zároveň se jí i dobře jedly. Když připravoval vaječnou omeletu, zpestřil ji drobnými tečkami kečupu, což paní Liškové opakovaně vykouzlilo úsměv na tváři. Paní Lišková měla velmi ráda bábovku. Pan Liška jí každý den krájel bábovku na kostičky, aby ji mohla snadno uchopit. Právě radost, kterou $z$ bábovky měla, pana Lišku motivovala $k$ tomu, aby ji pravidelně kupoval. Chodil pro ni do obchodu i v zimě, když bylo náledí. Uvažoval nad jídlem jako nad něčím, čím může udělat své ženě radost.

Nutno ovšem dodat, že pan Liška měl na nakupování a vaření mnohem větší prostor než pan Pařízek. K Liškovým chodil Petr nebo jiná asistentka z Přístavu pět dní v týdnu na čtyři až pět hodin, zatímco u Pařízkových byly odlehčovací služby poskytovány v mnohem menším rozsahu. Navíc pan Pařízek se staral jak o manželku, tak o sestru. Skutečnost, že značnou část péče o paní Liškovou zajištoval asistent a asistentky Př́́stavu, umožňovala panu Liškovi věnovat větší pozornost jíllu, jeho výběru a prípravě.

Na rozdíl od pana Lišky narážel pan Pařizek při pečování o obě ženy na skutečnost, že ho v péči často neměl kdo zastoupit. Obě ženy na něm byly v mnoha ohledech závislé, což se ukázalo jako problematické. Například když paní Pařízková upadla na balkóně, byl pan Pařizek zrovna na nákupu. Nemohla se zvednout a sestra pana Pařízka neměla telefon, aby bratrovi zavolala. Pan Pařízek vzpomíná, jak tehdy přišel domů: 
Ode dveři slyším sestru, jak na mě volá, at' rychle prĭjdu, že manželka leží na balkóně na zemi. (...) Zakopla, spadla, ted'na ni pršelo, padal sníh. Ona tam ležela dvacet minut, a já to nevěděl. Coural jsem po hypermarketu.

Nezastupitelnost pana Paříza v době nákupů řešila rodina tím, že pořídila sestře pana Pařízka mobilní telefon. Díky mobilnímu telefonu mohla sestra pana Pařízka komunikovat s dalšími členy rodiny a zavolat pomoc v případě potřeby. Mobilní telefon se pro ni stal pomocníkem a spojencem. Přispěl k posílení její autonomie a vlastně i autonomie paní Pařízkové.

Skutečnost, že pana Paříza často neměl v péči kdo zastoupit, pro něj znamenala značnou dlouhodobou zátěž. Nemohl si jen tak vyrazit na sraz s kamarády nebo sportovat, jako to dělával pan Liška. Neměl v rámci každodenní péče vyhrazený prostor na volný čas, kdy by se mohl věnovat svým zálibám, odpočívat a nabírat průběžně sílu na pečování o obě ženy. $V$ tomto ohledu měl pan Liška velkou výhodu, že v pracovních dnech se péči o paní Liškovou hodně věnoval Petr, a on mohl pečovat sám o sebe. Přestože pana Pařízka péče o obě ženy plně zaměstnávala a vytěžovala, nijak si nenaříkal. Snažil se brát vzniklou situaci s nadhledem i navzdory tomu, že se postupně začal zhoršovat jeho zdravotní stav.

Ani paní Pařízková si nestěžovala. Byla to skromná starší paní, která byla za manželovu péči nesmírně vděčná. A mluvila o něm velmi pěkně: „Manžel je jedinečný. On dělá všechno." (z rozhovoru s paní Pařízkovou při zúčastněném pozorování) Pouze jednou si mi posteskla: "Je to hrozné, když člověk musí čekat. Musím být trpělivá." (z rozhovoru s paní Pařízkovou při zúčastněném pozorování) Paní Pařízková přiliš̌ své potřeby neverbalizovala a čekala, až si pan Pařízek všimne. Podobně jako muži využívali při péči o ženy různých repertoárů, zapojovaly ženy do komunikace svých potřeb určité repertoáry, do jejichž kompozice vstupoval i gender. Pomocí určitých gest a projevů, jež byly součástí repertoárů jejich komunikace, zjednávaly různé formy femininity a maskulinity.

Například tiché čekání paní Pařízkové, až manžel príide do jejího pokoje a zeptá se, jestli něco nepotřebuje, bývalo v kontrastu s průběžným voláním sestry pana Pařízka, aby bratr přišel k jejímu lưžku. Otevřené verbalizování aktuálních potřeb ze strany sestry pana Pařízka bylo výrazem prímějšího a razantnějšího sebeprosazování.

Přestože pro paní Pařízkovou bylo někdy čekání těžké, nesnažila se své potřeby víc prosazovat, ale být trpělivější. Skromnost, vděčnost a trpělivost paní Pařízkové ovšem měly své limity z hlediska každodenní péče. Pan Pařízek si byl těchto limitů vědom: "Spiš čeká. A to je špatně, zejména když má žízeň nebo tak." (z rozhovoru s panem Pařízem) Na druhou stranu si manželčiny skromnosti a vděčnosti cenil. 


\section{NV STATI / ARTICLES}

Manželka vždycky za všechno strašně děkuje. To sestru ani nenapadne, ale manželku vždycky, a to tak potěší. (...) Ona je za všechno velice vděčná, což je úžasné. (pan Pařízek)

Ve výpovědích pana Pařízka i ve vyjádřeních paní Pařízkové Ize vysledovat určitou ambivalenci k trpělivosti a vděčnosti, kterou paní Pařízková manželovi projevovala. Pro paní Pařízkovou bylo na jednu stranu někdy těžké trpělivě čekat, až manžel přijde do jejího pokoje a zeptá se jí, jestli nechce napít nebo doprovodit na toaletu. Na druhou stranu mu byla vděčná, že se o ni stará. Věděla, že pro něho není snadné pečovat o ni a sestru zároveň, a nechtěla ho ještě víc zatěžovat. Navíc měla vyzkoušené, že manžela její vděčnost těší. Upozad'ování vlastních potřeb, jež jsem pozorovala u paní Pařízové, napomáhali udržovat oba společně navzdory této ambivalenci.

Sestra pana Pařízka komunikovala o svých potřebách otevřeně a přímo. K jejímu razantnějšímu prosazování potřeb se ovšem pan Pařízek stavěl rezervovaně. Její průbojnost při vyjadřování vlastních potřeb v rozhovoru interpretoval jako př́lišnou vybíravost a náročnost. Napríklad kosmetiku, kterou si jeho sestra byla zvyklá kupovat, považoval za př́liš drahou, což se projevilo tak, že sestra dostala k Vánocům jinou, levnější kosmetiku, než si prála. Pan Pařízek totiž doma „držel kasu“ a měl poslední slovo v tom, co se koupí, a co ne.

Pro pana Lišku se po určité době stalo náročné mytí jeho manželky. Jejich koupelna nebyla príliš velká. Pan Liška ji upravil tak, aby se do ní vešli dva lidé, a jeden tak mohl pomáhat paní Liškové do vany. Zpočátku, než začali využívat služeb Přístavu, doprovázel do vany manželku sám. Později, když si již nebyl jistý, že dokáže manželku udržet při vstupu do vany a výstupu z ní, aby mu manželka nevyklouzla a neupadla, přenechal koupání Petrovi a asistentkám Přístavu.

On se bál, že by mu paní upadla, že by ji nezvedl. Vím, že mi párkrát řikal, že mu upadla. Je hezké, že $v$ tomhle věku dokáže pěkně rozlišit, na co stačí, a na co už nikoliv. (Petr)

Pády patří mezi nejčastější přičinu, proč jsou lidé v seniorském věku umistováni do zařízení dlouhodobé péče (Glenner a kol. 2012). Lidé s demencí, kteří mají problémy s pohyblivostí a koordinací těla, jsou vůči pádům velmi zranitelní. Rovněž pro paní Liškovou znamenal pád, při němž si zlomila nohu v krčku, konec domácí péče. Byla převezena do nemocnice, kde po operaci stehenní kosti dostala zápal plic a po několika týdnech zemřela v nedaleké LDN. Ze dne na den bylo přetato harmonické proplétání péče pana Lišky s péči Petra a dalších pracovnic Př́stavu v domácím prostředí. Skončilo společné zpívání ve sprše, procházky na oblíbená místa i pojídání bábovky po ránu. Nečekaný a nevítaný předěl měl zásadní dopad na život paní Liškové - přetnul 
mnohá spojení, jež udržovala kontinuitu jejího života. Usnadnění přechodu z péče v domácím prostředí do péče v nemocnici či v jiném zařízení zůstává v prípadě lidí žijících s demencí velkou výzvou, a to nejen pro primární pečující, ale i pro poskytovatele zdravotních a sociálních služeb. U paní Pařízkové a sestry pana Pařízka se podařilo, aby mohly zemřít pokojně doma, obklopeny těmi, které znaly a měly rády. Přechod do domácí hospicové péče Přístavu proběhl u obou z nich hladce. Proplétání péče pana Pařízka s péčí odlehčovacích a následně hospicových služeb Přístavu doprovodilo obě ženy až na konec jejich života.

\section{Závěr}

Domov je jedním z kličcvých materiálních a symbolických zdrojů pro utváření identity člověka (Dyck et al. 2005). U stárnoucích osob s demencí bývá domov spjat se zkušeností osobní svébytnosti a představou známého bezpečného prostoru (Kamphof, Hendriks 2020), což je také jedním z důvodů, proč se řada rodin snaží pečovat o svého stárnoucího rodinného príslušníka s demencí $v$ domácím prostředí, jak nejdéle je to možné. Poskytování a prijijimání péče $v$ domácím prostředí zahrnuje celou řadu vyjednávání, do nichž významně vstupuji i sociomateriální podmínky a socioprostorové uspořádání domova (Dyck et al. 2005). Zúčastněné pozorování v rodinách mi umožnilo zkoumat péči jako interaktivní proces, jenž je spoluutvářen v každodenní interakci mezi pečujícím a opečovávanou osobou. Proces, do jehož kompozice vstupují i genderová očekávání a struktury. Měla jsem možnost pozorovat, na jaké činnosti a potřeby žen se muži při pečování soustřed'ovali a jaké repertoáry péče používali. Jejich pečování bylo strukturováno dvěma repertoáry péče: provozním repertoárem a repertoárem laskavosti a radosti. Tyto dva repertoáry péče zahrnují hodnoty, strategie, dovednosti, postupy a praktiky mužů pečujících o ženy doma. Provozní repertoár péče využívali ke koordinaci péče a zajištování základních potřeb žen oba primární pečující. Repertoár laskavosti a radosti soustřed'ující se na to, aby každodenní činnosti byly pro opečovávanou osobu př́ijemné, zapojoval do pečování jen jeden z nich. Odlišné pečující praktiky mužů, které jsem při pozorování zaznamenala, jsou ukázkou toho, že rozdíly $v$ pečování nejsou dány biologicky, ale jsou utvářeny $v$ návaznosti na genderovou socializaci, sociomateriální podmínky, zkušenosti, znalosti a dovednosti pečující osoby. Také skutečnost, že péče formálních pečovatelů Petra a paní Eleny probíhala v repertoáru laskavosti a radosti, je dokladem toho, že rozlišování péče na "mužskou" a „ženskou“ je generalizace, která neodpovídá tomu, jak muži a ženy $\checkmark$ praxi pečují.

$\checkmark$ rodině, kde přetrvávala tradičně nastavená genderová dělba práce $v$ domácnosti, bylo pro muže náročnější stát se primárním pečujícím. Nicméně, jak ukazuje př́iklad Pařízových, i muž, který celý život nevařil, se může ve svých osmdesáti letech naučit 


\section{NV STATI / ARTICLES}

vařit a zajištovat chod domácnosti. Na rozdíl od toho v rodině, kde předchozí zapojení muže do péče o děti a do činností spojených s chodem domácnosti bylo mezi manžely vyváženější, neznamenalo rozhodnutí stát se primárním pečujícím tak komplikovaný a nesnadný přechod (Moser, Law 1998). V prípadě Liškových pan Liška aktivoval dř́vější spojení s určitými aktéry (Moser, Law 1998; Latour 2005), navázal na předchozí zkušenosti a dále své dovednosti rozvinul při péči o manželku.

$\checkmark$ průběhu pečování čelili muži jako primární pečující řadě nesnází a problémů. Kromě vaření se $v$ rámci každodenní péče jednalo o hygienu ve vaně a problém nezastupitelnosti. V případě hygieny ve vaně požádal pan Liška Přístav o rozšíření asistence, a zapojil tak Petra do sprchování paní Liškové. Ten po něm tuto činnost velmi obratně převzal s respektem ke křehkosti paní Liškové. Zapojení dalších aktérů do péče zároveň významně napomohlo při řešení nezastupitelnosti pana Pařízka. Primárně pečujicí muži nevnímali zapojení dalších aktérů a aktérek do péče nijak úkorně, ve smyslu, že se jim do pečování někdo „plete", naopak ho velmi vítali. Díky zapojení dalších aktérů a aktérek do péče nebyli kontinuálně vystaveni tak velké zátěži spojené s pečováním a snadněji se jim udržovala hranice, aby měli i nějaký čas pro sebe a své aktivity (Dudová, Vohlídalová 2018). Zejména panu Liškovi pečování Petra a asistentek z Přístavu, kteří se o paní Liškovou starali ke konci každý všední den až pět hodin, poskytlo prostor, že mohl pečovat i sám o sebe, chodit sportovat a udržovat sociální vazby s přáteli. A měl tak dostatek energie, aby do pečování často zařazoval repertoár laskavosti a radosti. Navíc rozšiřování a diverzifikace sítě aktérů zapojených do péče (včetně např. mobilního telefonu) významně přispěly k udržitelnosti a kvalitě péče o ženy s demencí v domácím prostředí. Na příběhu Pařízových vidíme, jak dưležitou roli v pečování hrají sociomateriální podmínky. Ekonomické a lidské zdroje, které mají primární pečující k dispozici, významně ovlivňují, zda do své péče zapojí i repertoár laskavosti a radosti.

Pojímání péče jako interaktivního procesu mi umožnilo zachytit genderový rozměr pečování v několika rovinách: 1) v charakteru některých potřeb žen, o něž se pečuje; 2) ve způsobu, jak ženy své potřeby vyjadřují; 3) jak pečující na tyto potřeby a zpưsob jejich komunikace reagují. Určité potřeby žen byly ovlivněny tím, jak ženy zjednávaly svůj gender. Např́klad u sestry pana Pařízka zjednávání genderu spoluutvářelo její potřebu péče o plet', vlasy a celkový vzhled. V případě paní Liškové zase zjednávání genderu ovlivňovalo její potřebu fyzického kontaktu a blízkosti i způsoby, jak tuto potřebu projevovala. Pan Liška, Petr a asistentky Přístavu se snažili naslouchat potřebám a práním žen, o které se starali, a pokud to bylo možné, hledali cesty, jak spolu s nimi tyto potřeby a prání naplnit. U pana Pařízka byla situace komplikovanější, ne snad že by nebyl ochotný vyjít sestře vstříc, ale i kvưli velké vytiženosti neměl pro některé její potřeby a razantnější způsob, jakým s ním o nich komunikovala, př́liš pochopení.

Péči jako interaktivní proces Ize připodobnit k řece. Podobně jako řeka ani péče 
není ničím jednolitým, je různorodá a proměňuje se. Má řadu zákrut, meandrů, ale i "stojatých vod". Někdy plyne hladce, jindy se táhne. Některé úseky jsou pestré, jiné spiše monotónní. Tak jak jsem měla možnost pečování o ženy s demencí v rodinách pozorovat, jednalo se o proces, v němž důležitou roli hrálo opakování každodenních činností, které napomáhalo strukturovat čas během dne a přispívalo k udržování kontinuity života žen s demencí. Přestože se primárně pečující muži dostávali do situací, jež pro ně byly náročné a z dlouhodobého hlediska i vyčerpávající, dokázali znovu a znovu v sobě najít sílu a dál o ženy pečovat, v prípadě pana Pařízka je doma doprovodit až na konec jejich života.

\section{Literatura}

Agich, G. J. 2003. Dependence and Autonomy in Old Age: Ethical Framework for Longterm Care. Cambridge \& New York: Cambridge University Press.

Alzheimer Europe. 2019. Report: Overcoming Ethical Challenges Affecting the Involvement of People with Dementia in Research: Recognising Diversity and Promoting Inclusive Research. Luxembourg: Alzheimer Europe. Staženo 23. 3. 2021. (www.alzheimer-europe.org/Publications/Alzheimer-Europe-Reports).

Arber, S., N. Gilbert. 1989. Men: the Forgotten Carers. Sociology. 23 (1): 111-118, https://doi.org/10.1177/0038038589023001008.

Black, R. M. 2005. Intersections of Care: An Analysis of Culturally Competent Care, Client Centred Care, and the Feminist Ethics of Care. Work 24 (4): 409-422.

Butler, J. 1990. Gender Trouble. New York: Routledge.

Butler, J. 1993. Bodies That Matter: On The Discursive Limits of "Sex". New York: Routledge.

Butler, J. 2003. Trampoty s rodom. Feminizmus a podrývanie identity. Bratislava: Aspekt.

Butler, J. 2004. Undoing Gender. New York: Routledge.

Comas-d'Argemir, D., M. Sorronellas. 2019. Men as Carers in Long-Term Caring: Doing Gender and Doing Kinship. Journal of Family Issues. 40 (3): 315-339, https://doi.org/10.1177/0192513X18813185.

Cussins, Ch. 1996. Ontological Choreography: Agency through Objectivication in Infertility Clinics. Social Studies of Science 26 (3): 575-610, https://journals.sagepub.com/ doi/10.1177/030631296026003004.

ČSÚ. 2020. Zaostřeno na ženy a muže 2020. Praha: Český statistický úřad. Staženo 26. 5. 2021 (www.czso.cz/documents/10180/120583268/30000220.pdf/45d09d6e-670e4d7f-842d-3f2a5bfc4201?version=1.3).

Denzin, N. K. 1997. Interpretative Ethnography: Ethnographic Practices for the 21st Century. Thousand Oaks \& London \& New Delhi: SAGE Publication.

Denzin, N. K., Y. S. Lincoln (eds.). 2008. The Landscape of Qualitative Research. Los Angeles: SAGE Publication.

Dudová, R. 2015. Postarat se ve stáři. Rodina a zajištění péče o seniory. Praha: Sociologické nakladatelství (SLON). 


\section{NV STATI / ARTICLES}

Dudová, R., M. Vohlídalová. 2018. Muži a ženy pečující o seniory v rodině. Sociologický časopis 54 (2): 219-251, https://doi.org/10.13060/00380288.2018.54. 2.400.

Dudová, R., R. Volejníčková. 2014. Proč ženy pečují? Gender a neformální péče o seniory. Gender, rovné prĭležitosti, výzkum 15 (1): 41-54, http://dx.doi.org/10.13060/12130028.2 014.15.1.100.

Dyck, I., P. Kontos, J. Angus, P. McKeever. 2005. The Home as a Site for a Long-term Care: Meanings and Management of Bodies and Spaces. Health \& Place 11 (2): 173-185, https://doi.org/10.1016/j.healthplace.2004.06.001.

Emerson, R. M., R. I. Fretz, L. L. Shaw. 1995. Writting Ethnographic Fieldnotes. Chicago \& London: The University of Chicago Press.

Flick, U. 1998. An Introduction to Qualitative Research. London: SAGE Publications.

Glenner A. J., M. J. Stehman, J. Davagnino, J. M. Galante, L. M. Green. 2012. Péče o člověka s demencí. Praha: Portál.

Hašková, H., R. Dudová. 2017. Precarious Work and Care Responsibilities in the Economic Crisis. European Journal of Industrial Relations 23 (1): 47-63, http://journals.sagepub. com/doi/abs/10.1177/0959680116672279.

Haškovcová, H. 2010. Fenomén stárí. Praha: Havliček Brain Team.

Hradcová, D., M. Synek, I. Holmerová, J. Zgola. 2020. Promoting the Enjoyment of Food in Dementia Care: The Bon Appetit Intervetion in Care Homes. Pp. 244-259 in J. Manthorpe, E. Moniz-Cook (eds.). Timely Psychosocial Interventions in Dementia Care: Evidence Based Practice. London: Jessica Kingsley Publishers.

Chaloupková Klímová, J. 2012. Neformální péče v rodině: sociodemografické charakteristiky pečujíích osob. Data a výzkum SDA Info 7 (2): 107-124, http://dx.doi.org/10.13060/2336 2391.2013.127.2.39.

Janebová, R. 2008. Moc a autorita: genderové hledisko. Pp. 39-55 in R. Janebová, M. Kappl, M. Smutek (eds.). Sociální práce mezi pomocí a kontrolou. Hradec Králové: Gaudeamus.

Kamphof, I., R. Hendriks. 2020. Beyond Façade: Homemaking and Thruthfulness in Dementia Care. Pp. 271-292 in B. Pasveer, O. Synnes, I. Moser (eds.). Ways of Home Making in Care of Later Life. London: Palgrave Macmillan, https://doi.org/10.1007/978981-15-0406-8.

Křižková, A., H. Maříková, K. Pospíšilová, R. Marková Volejnićková, 2019. Rozdily v odměňování žen a mužư v ČR - Pracoviště, zaměstnání, stejná práce a rozklad faktorü. Praha: Ministerstvo práce a sociálních věcí.

Kuchařová, V., J. Barvíková, S. Höhne, K. Janurová, O. Nešporová, J. Paloncyová, K. Svobodová, L. Vidovićová. 2019. Česká rodina na počátku 21. století. Praha: Sociologické nakladatelství (SLON).

Latour, B. 2005. Reassembling the Social. Oxford: Oxford University Press.

Law, J. 2010. Care and Killing: Tensions in Veterinary Practice. Pp. 57-72 in A. Mol, I. Moser, J. Pols (eds.). In Care in Practice: On Tinkering in Clinics, Homes and Farms. Bielefeld: Transcript.

Letherby, G. 2003. Feminist Research in Theory and Practice. Philadelphia: Open University Press. 
Mátl, O., M. Mátlová, I. Holmerová. 2016. Zpráva o stavu demence 2016. Praha: Česká alzheimerovská společnost, o.p.s.

Moser, I., J. Law, 1998. Přechody snadné, přechody nesnadné aneb o heterogenní ekonomii subjektivity. Biograf 15-16: 1-22. Staženo 29. 1. 2017. (http://www.biograf.org/clanek. php?clanek=1502).

Oakley, A. 2000. Pohlaví, gender a společnost. Praha: Portál.

Pols, J. 2005. Když se myje občan: mytí, čistota a občanství v péči o duševní zdraví. Biograf 38: 1-25. Staženo 23. 3. 2021. (http://www.biograf.org/clanek.php?clanek=3801).

Pols, J. 2012. Care at a Distance: On the Closeness of Technology. Amsterdam: Amsterdam University Press.

Přidalová, M. 2006. Mezigenerační solidarita a gender. (Pečující dcery a pečující synové). Gender, rovné př́ležitosti, výzkum 7 (1): 1-5.

Russell, R. 2007a. The Work of Elderly Men Caregivers. From Public Careers to an Unseen World. Men a nad Masculinities 9 (3): 298-314, https://doi. org/10.1177/1097184X05277712.

Russell, R. 2007b. Men Doing Women's Work: Elderly Men Caregivers and the Gendered Construction of Care Work. The Journal of Men's Studies 15 (1): 1-18, https://doi. org/10.3149/jms.1501.1.

Simpson, R. 2009. Men in Caring Occupations: Doing Gender Differently. London: Palgrave Macmillan.

Synek, M., D. Hradcová, D. Jahodová, R. Carboch. 2017. O (ne)soudržnosti pečování: Mnohočetné ontologie života s demencí. Biograf 65-66: 5-51.

Vidovićová, L., L. Galčanová, M. P. Kafková, D. Sýkorová. 2013. Stáři ve městě, město $v$ životě seniorů. Praha: Sociologické nakladatelství (SLON).

West, C., D. H. Zimmerman, 2008. Dělat gender. Sociální studia 5 (1): 99-120.

Zgola, J., G. Bordillon, 2013. Bon appetit: radost z jídla v dlouhodobé péči. Praha: Česká alzheimerovská společnost.

c) BY-NC Dita Jahodová, 2021.

(c) BY-NC Sociologický ústav AV ČR, v. v. i., 2021.

Mgr. Dita Jahodová vystudovala genderová studia na Fakultě humanitních studií Univerzity Karlovy. Věnuje se tématům spojeným s fungováním genderového řádu, tělem a tělesností, lékařskou péčí, medikalizací, stigmatizací, zneviditelňováním a sociálním vyloučením. Intenzivně se také zabývá problematikou (ne)rovného odměňování žen a mužů. V rámci svého působení v Centru pro studium dlouhověkosti a dlouhodobé péče Fakulty humanitních studií Univerzity Karlovy rozširrila svou oblast zájmu o péči o lidi s demencí. Kontaktní e-mail: dita.jahodova@gmail.com. 